Archive for

Organic Chemistry

Arkivoc 2019, part iv, 80-90

\title{
Synthetic studies toward eleganine A
}

\author{
Christopher F. Cain, Evan H. Howard, Justin A. Goodwin, and Juan R. Del Valle* \\ Department of Chemistry, University of South Florida, Tampa, FL 33620, USA \\ Email: delvalle@usf.edu
}

Dedicated to Prof. Stephen Hanessian for landmark contributions to the field of organic chemistry

Received 01-30-2019

Accepted 03-07-2019

Published on line 03-13-2019

\section{Abstract}

Eleganine $A$ is a cytotoxic indole alkaloid recently isolated from the leaves of Tabernaemontana elegans. Its unique structure arises from rearrangement of a canonical corynanthe skeleton, resulting in the presence of a 4-ethylidene-3-alkylproline core. Employing a chiron approach, we describe an efficient and scalable synthesis of the proline subunit of eleganine $A$, as well as efforts toward its proposed structure.
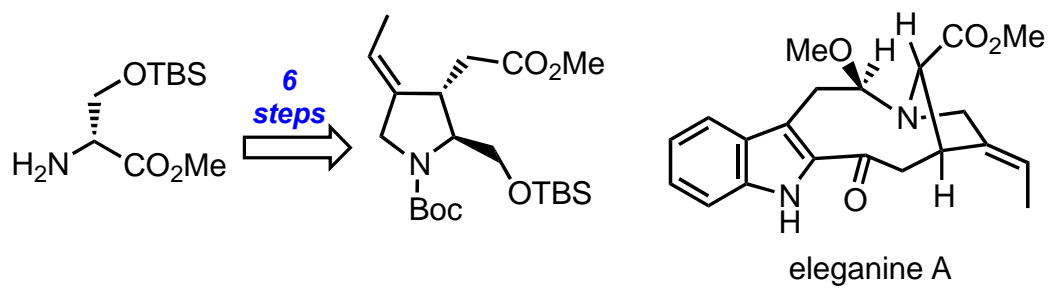

Keywords: Alkaloid, proline, total synthesis, natural products 


\section{Introduction}

Alkaloids belonging to the corynanthe family have long attracted the interest of synthetic chemists owing to their complex architectures and intriguing biological properties. These natural products feature the monoterpene connectivity shown in Figure 1 , typically resulting in tetrahydo- $\beta$-carboline core structures that can further rearrange to aspidosperma- or iboga-type alkaloids. ${ }^{1,2}$ In 2009, Ferreira and co-workers reported the isolation of eleganine A (1) from the leaves of Tabernaemontana elegans in Mozambique. ${ }^{3}$ Eleganine A exhibited cytotoxicity and induction of apoptosis in human hepatoma cells as measured in a trypan blue cell viability assay. In addition, compound $\mathbf{1}$ features an unprecedented azabicyclo[6.2.1]undecane core structure presumed to derive from rearrangement of the corynanthe monoterpene unit. Excelsinidine (2) ${ }^{4}$ and 17 -norexcelsinidine $(3)^{5,6}$ are naturally-occurring reduced congeners of eleganine $A$ featuring similar terpenoid connectivity. A recent biomimetic synthesis of $\mathbf{3}$ demonstrated its relationship to the geissoschizine skeleton using an elegant oxidative rearrangement approach. ${ }^{7}$ To date, there are no reported synthetic studies toward 1.

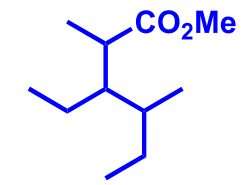

corynanthe alkaloid monoterpene unit

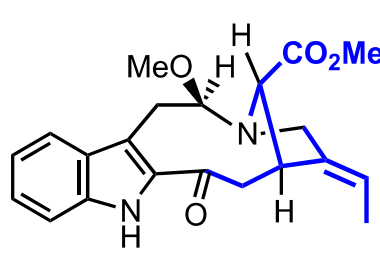

1 eleganine $A$

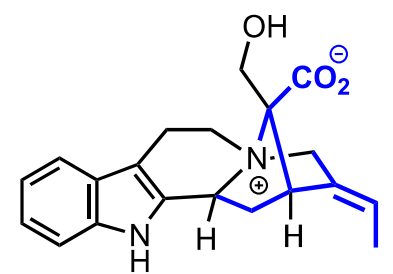

2

excelsinidine

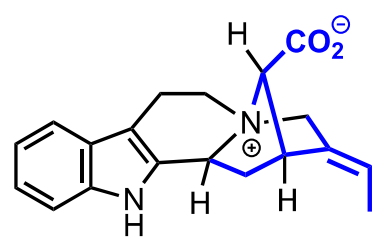

3

17-nor-excelsinidine

Figure 1. The corynanthe monoterpene unit and rearranged alkaloids featuring 4-ethylidene-3-alkylproline core structures.

In considering a modular synthetic approach to 1, we were intrigued by the presence of a 4-ethylidene3-alkylproline embedded within a new alkaloid framework. We previously reported the synthesis of several 4alkylideneprolines, ${ }^{8-10}$ which are found in a select number of natural products including the lucentamycins, ${ }^{11,12}$ isodomoic acids, ${ }^{13}$ and tomaymycin. ${ }^{14,15}$ Our strategy relied on an ester enolate-Claisen rearrangement to give the linear proline precursors, setting both stereocenters and the pendant alkene geometry in a single step. ${ }^{9}$ The $E$ configuration of the alkene in $\mathbf{1}$ precluded application of this approach, as the chair-like transition state of the rearrangement provides the opposite alkene geometry. This prompted us to consider a conceptually novel approach toward the 4-ethylidene-3-alkylprolines subunits of 1-3. Here, we report the stereospecific synthesis of the fully elaborated core of eleganine $A$, as well as efforts toward its proposed structure.

\section{Results and Discussion}

Our retrosynthetic plan for eleganine $A$ is depicted in Figure 2. We envisioned that nucleophilic attack of the pyrrolidine nitrogen onto an oxocarbenium ion would provide the cyclic hemiaminal ether in the final step of the synthesis. Acylation of an appropriately substituted C2-lithiated indole with pyrrolidine derivative $\mathbf{5}$ could in turn provide 4. A protected 4-alkylidene-3-alkylprolinol (5) serves as the key intermediate in our synthetic plan, and its stereochemistry at C2 was traced back to D-serine as a chiral progenitor. We anticipated that the 
configuration of C3 could be set through a diastereoselective reductive Heck-type cyclization involving the vinyl halide and enoate groups in 6. The early formation of the C2-C3 bond in our approach enables the synthesis of large quantities of trans-substituted pyrrolidine $\mathbf{5}$, which we also viewed as a potential precursor to related indole alkaloids such as $\mathbf{2}$ and $\mathbf{3}$.

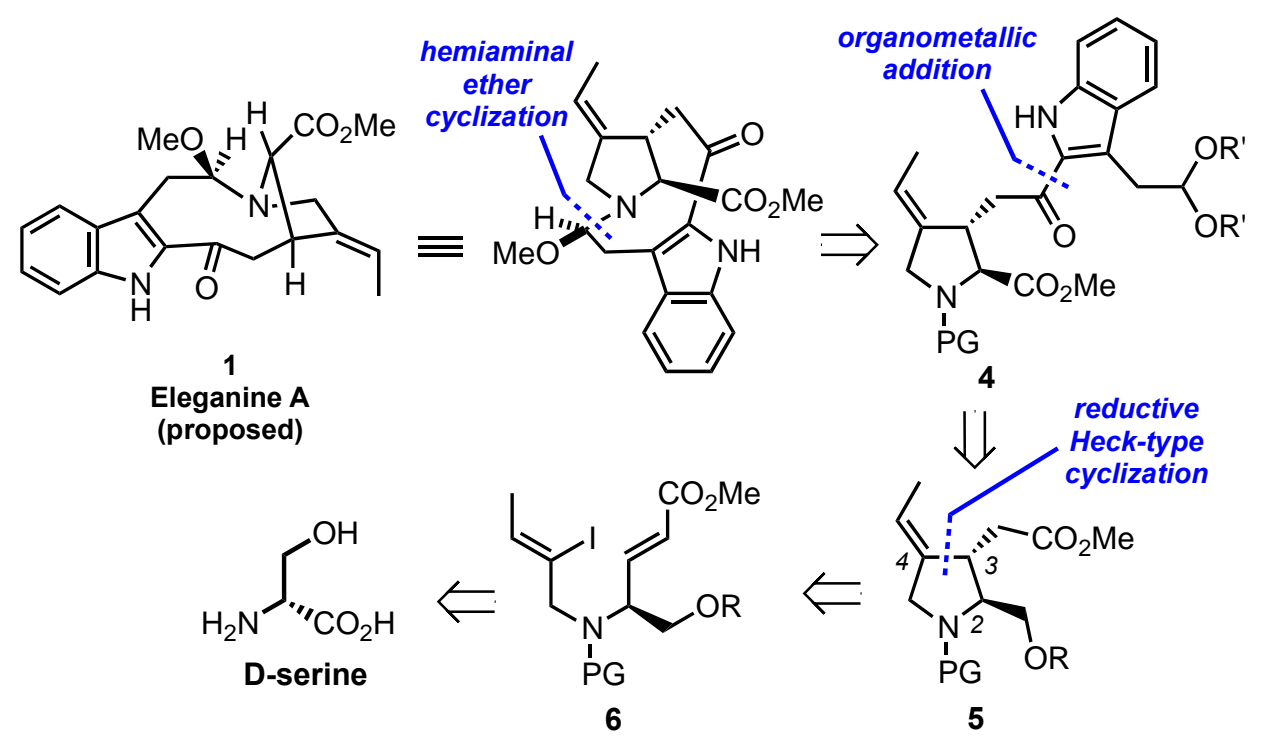

Figure 2. Retrosynthetic plan toward 1.

The synthesis commenced with alkylation of readily available D-serine derivative $7^{16}$ with (Z)-1-bromo-2iodobut-2-ene, ${ }^{17}$ followed by Boc protection and ester reduction with lithium borohydride (Scheme 1). Compound 8 was then converted to enoate $\mathbf{9}$ in 70\% yield using standard conditions. Reductive-Heck type cyclization of 9 was initially accomplished in the presence of excess $\mathrm{Ni}(\mathrm{COD})_{2}$ and triethylamine to give moderate yields of $\mathbf{1 0}$, along with various byproducts. Given the sensitive nature of the metal complex and required use of stoichiometric reagents, we explored catalytic systems as an alternative. Gratifyingly, we found that 20 mol\% of $\mathrm{Ni}\left(\mathrm{PPh}_{3}\right) \mathrm{Cl}_{2}$ in the presence of freshly activated zinc afforded the desired pyrrolidine 10 in $68 \%$ isolated yield. Analysis of the crude reaction mixture showed this transformation to be highly diastereoselective, with none of the minor cis isomer detected by ${ }^{1} \mathrm{H} N M R$. This selectivity may be attributed to the higher activation barrier associated with a C2,C3-cis transition state, as well as conformational preorganization governed by 1,3-allylic strain, as shown in Scheme 1. In anticipation of nucleophilic attack onto the carbonyl in 10, we then converted the ester into Weinreb amide $\mathbf{1 1}$ to provide another potential substrate for indole acylation. 


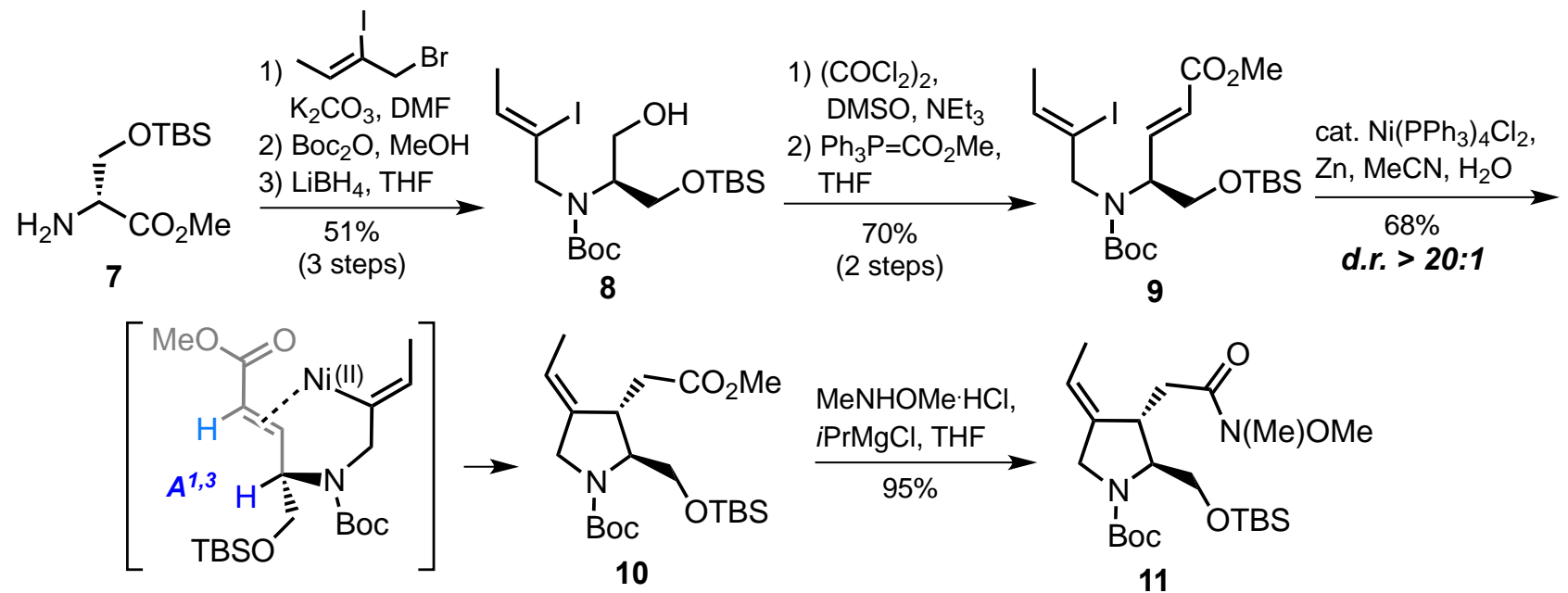

Scheme 1. Synthesis of 4-ethylidene-3-alkylprolinol derivative 11.

Initial attempts to join the indole and pyrrolidine fragments relied on $\mathrm{C} 2$ lithiation of dimethyl acetal derivative 13 (Scheme 2). After screening several conditions, we found lithium tetramethylpiperidine to be the optimal base for $\mathrm{C} 2$ metalation. ${ }^{18}$ This was verified by trapping the lithiated intermediate with ethyl chloroformate to give 14 in good yield. Despite this encouraging result, we were unable to promote the condensation of 13 with either methyl ester $\mathbf{1 0}$ or Weinreb amide $\mathbf{1 1}$ to give 15. Attempts to employ other protected indoles (replacement of the $\mathrm{N}$-Boc group) or active ester derivatives of $\mathbf{1 0}$ also failed to provide appreciable amounts of acyl indole products.

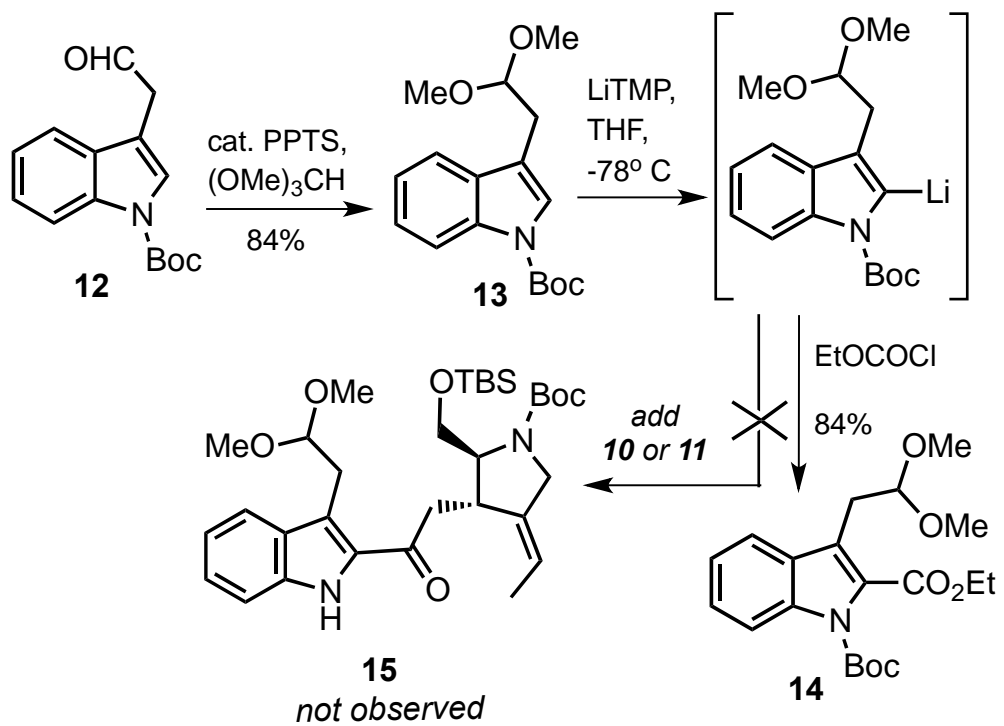

Scheme 2. Attempted synthesis of $\mathbf{1 5}$ via direct indole acylation.

As an alternative to direct indole acylation, we turned to the alkyne heteroannulation strategy depicted in Scheme 3. Thus, alkynylation of 11 with 4,4-dimethoxybutyne ${ }^{19}$ afforded ynone 16, which would serve as a substrate for Larock indole synthesis. The regioselectivity of Larock heterannulation has been extensively studied and is thought to be governed primarily by steric factors in the case of asymmetric alkynes. ${ }^{20}$ This $^{2}$ selectivity arises during the alkyne carbopalladation step wherein the larger substituent prefers to orient itself 
away from the forming carbon-(aryl)carbon bond. Despite the ubiquity of this reaction, there are few reported examples of Larock indole syntheses performed on ynoate or ynone substrates, or on the influence of electronic factors on alkyne insertion regioselectivity. ${ }^{21-23} \mathrm{~A}$ relevant study by Chuawong and coworkers employed para-substituted diphenylacetylenes to establish a positive Hammett correlation between electronwithdrawing substituents and regioselectivity. ${ }^{24}$ In these cases, polarization of the alkyne results in preferred migration of the electrophilic Pd center to the more electronegative carbon. We observed regioselectivity consistent with this model in the heteroannulation of 16 with 2-iodoaniline. In the presence of $\mathrm{Pd}\left(\mathrm{PPh}_{3}\right)_{4}$ and $\mathrm{K}_{2} \mathrm{CO}_{3}$ in THF, indole 15 was obtained in $55 \%$ yield along with $18 \%$ of the undesired regioisomer, which was readily separated by flash chromatography.

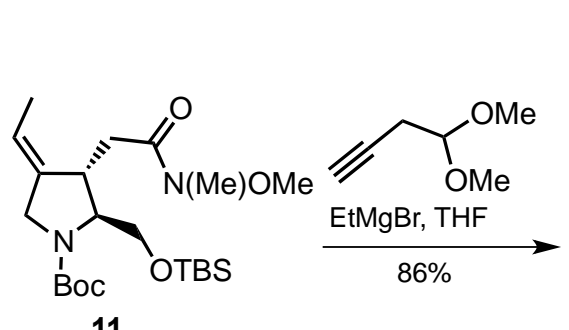

11

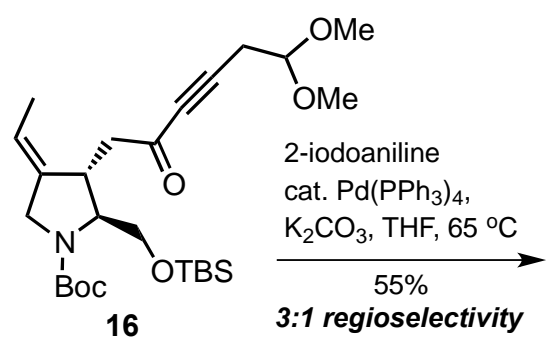

16

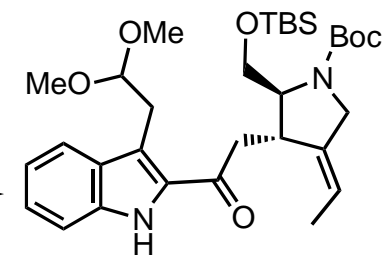

15

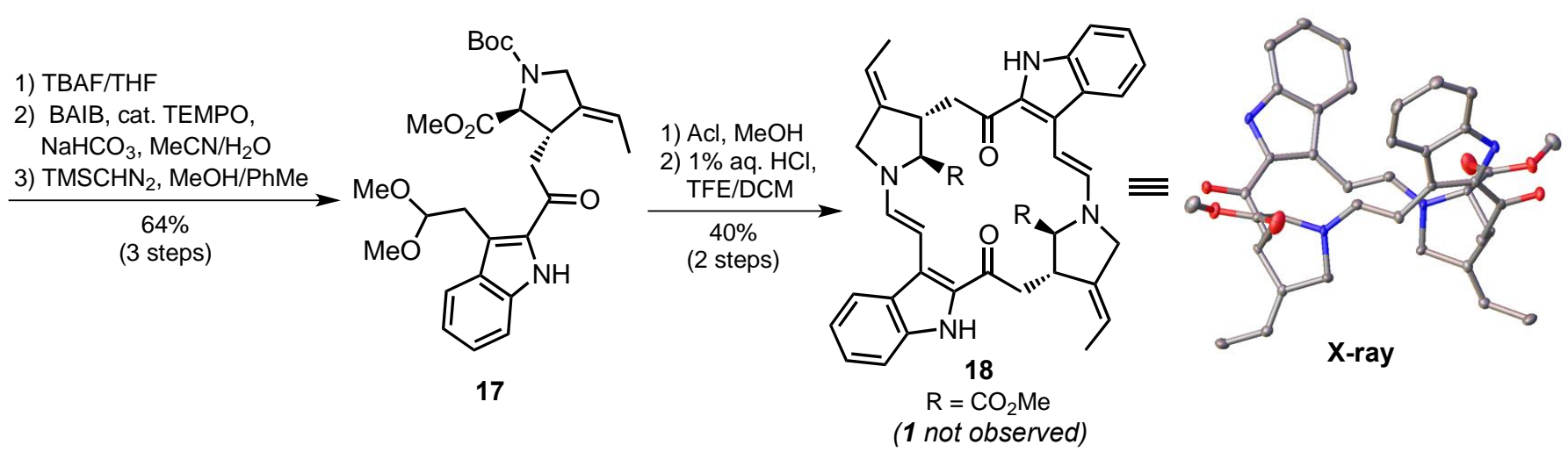

Scheme 3. Synthesis and X-ray structure of enamine dimer 18.

With intermediate $\mathbf{1 5}$ in hand, the final stages of the synthesis required oxidation of the protected primary hydroxyl group and acid-promoted cyclization to form the hemiaminal ether. Thus, silyl ether cleavage with TBAF was followed by oxidation using (bisacetoxyiodo)benzene and catalytic TEMPO. Esterification of the crude carboxylic acid with trimethylsilyldiazomethane then afforded $\mathbf{1 7}$ in 64\% combined yield over 3 steps. Oxidation immediately following silyl ether cleavage and flash chromatography was critical, as the resulting alcohol was found to decompose over several hours at room temperature. We screened various conditions to promote Boc deprotection and concomitant cyclization of 17. While one-pot procedures failed to afford desired product, we found that treatment with acidic methanol cleaved the Boc group, leaving the dimethyl acetal intact. The crude amine was then treated with dilute aq. $\mathrm{HCl}$ in trifluoethanol/DCM, resulting in the formation of a compound with ${ }^{1} \mathrm{H}$ NMR signals characteristic of a trans-enamine. This solid was recrystallized from chloroform/hexanes and X-ray diffraction confirmed its structure to be that of dimeric species 18. Despite several efforts to obtain monomeric cyclization products, we found that acidic conditions consistently favored the formation of $\mathbf{1 8}$ over the heminaminal ether $\mathbf{1 .}$

In observing the apparently strong propensity for formation of dimeric enamine $\mathbf{1 8}$, we considered the influence that the relative stereochemistry at C2 may have on the final cyclization. The C2-C3 trans 
relationship in eleganine A was originally assigned on the basis of anisotropic shielding of the methyl ester NMR signal by the indole $\pi$ electron cloud. ${ }^{25}$ This phenomenon has been observed in a variety of related nonrearranged monoterpene alkaloids including vobasine and tabernaemontanine. ${ }^{26}$ However, in most cases the bridgehead carbon in question bears the opposite configuration, placing the ester group in closer spatial proximity to the indole ring. Subsequent to the isolation of 1 , Girardot et al. identified a reduced congener of 1, dihydroeleganine A, in which the C2-C3 relationship was characterized as cis. ${ }^{27}$ This raises the possibility that the pyrrolidine ring in eleganine $A$ may also harbor a cis substitution pattern and that this configuration may influence the stability of the product, or its propensity for dimerization.

\section{Conclusions}

In summary, we have described a concise approach to the synthesis of the eleganine A core structure using Dserine as a chiral synthon. Our strategy relies on a highly diastereoselective reductive Heck-type coupling to form the pyrrolidine ring and a Larock heteroannulation to install the indole. Attempts at late-stage hemiaminal ether cyclization resulted in the unexpected formation of a dimeric enamine whose structure was confirmed by $\mathrm{X}$-ray diffraction. We are currently exploring the factors that influence the final hemiaminal ether formation step, including the possibility of configurational missassignment at the bridgehead methine in 1. A select number of monterpene alkaloids derived from corynanthe precursors feature a rearranged skeleton harboring the 4-alkylidene-3-alkylproline core of eleganine A. The described approach should find utility in the syntheses of these and related natural products.

\section{Experimental Section}

General. Unless stated otherwise, reactions were performed in flame-dried glassware under a positive pressure of argon or nitrogen gas using dry solvents. Commercial grade reagents and solvents were used without further purification except where noted. Toluene, $\mathrm{Et}_{2} \mathrm{O}, \mathrm{DCM} \mathrm{DMF}$, and MeCN were used following passage through a Pure Process Technologies solvent purification system. Other anhydrous solvents were purchased directly from chemical suppliers. Thin-layer chromatography (TLC) was performed using Merck 60 F254 silica gel pre-coated glass-backed plates $(0.25 \mathrm{~mm})$. Flash chromatography was performed using silica gel cartridges (40-65 $\mu \mathrm{m}$ particle size). Reaction progress was judged by TLC analysis (single spot/two solvent systems) using a UV lamp, CAM (ceric ammonium molybdate), ninhydrin, or basic $\mathrm{KMnO}_{4}$ stain(s) for detection purposes. NMR spectra were recorded on a 400 or $500 \mathrm{MHz}$ spectrometer. Proton chemical shifts are reported as $\delta$ values relative to residual signals from deuterated solvents $\left(\mathrm{D}_{2} \mathrm{O}, \mathrm{CDCl}_{3}, \mathrm{CD}_{3} \mathrm{OD}\right.$, or DMSO- $\left.d_{6}\right)$.

tert-Butyl (R,Z)-(1-((tert-butyldimethylsilyl)oxy)-3-hydroxypropan-2-yl)(2-iodobut-2-en-1-yl) carbamate (8). A solution of H-Ser(TBS)-OMe (7) ${ }^{16}(22.3 \mathrm{~g}, 95.6 \mathrm{mmol})$ and $(Z)-1$-bromo-2-iodobut-2-ene ${ }^{17}(12.5 \mathrm{~g}, 47.8 \mathrm{mmol})$ in DMF was cooled to $0{ }^{\circ} \mathrm{C}$ and treated with $\mathrm{K}_{2} \mathrm{CO}_{3}(66.1 \mathrm{~g}, 478 \mathrm{mmol})$. After stirring vigorously for $48 \mathrm{~h}$ at rt, DMF was removed under reduced pressure and the crude material dissolved in EtOAc. The mixture was washed with sat. aq. $\mathrm{NH}_{4} \mathrm{Cl}$, the aqueous layer extracted with EtOAc, and the combined organic layers dried with $\mathrm{Na}_{2} \mathrm{SO}_{4}$ and concentrated. Purification via flash chromatography over silica gel (0-10\% EtOAc/hexanes) afforded the secondary amine intermediate as a yellow oil $\left(17.3 \mathrm{~g}, 87 \%\right.$ yield). ${ }^{1} \mathrm{H}$ NMR $\left(400 \mathrm{MHz}, \mathrm{CDCl}_{3}\right.$, mixture of rotamers): $\delta 5.82(\mathrm{~m}, 1 \mathrm{H}), 3.82(\mathrm{~m}, 2 \mathrm{H}), 3.71(\mathrm{~s}, 3 \mathrm{H}), 3.64-3.57(\mathrm{~m}, 1 \mathrm{H}), 3.45-3.39(\mathrm{~m}, 1 \mathrm{H}), 3.36(\mathrm{t}$, 
$1 \mathrm{H}$, J $5.1 \mathrm{~Hz}, 1 \mathrm{H}), 2.24$ (bs, $\left.1 \mathrm{H}), 1.76(\mathrm{~d}, J 6.3 \mathrm{~Hz}, 3 \mathrm{H}), 0.86(\mathrm{~s}, 9 \mathrm{H}), 0.03(\mathrm{~m}, 6 \mathrm{H}) ;{ }^{13} \mathrm{C} \mathrm{NMR}\left(100 \mathrm{MHz}^{\mathrm{C}} \mathrm{CDCl}\right)_{3}\right): \delta$ 173.3, 131.9, 109.8, 64.6, 61.1, 59.7, 51.9, 25.9, 21.8, 18.3, -5.4; HRMS (ESI-TOF) $\mathrm{m} / \mathrm{z}[\mathrm{M}+\mathrm{H}]^{+}$calcd for $\mathrm{C}_{14} \mathrm{H}_{29} \mathrm{INO}_{3} \mathrm{Si} 414.0956$, found 414.0972 .

The secondary amine above $(19.8 \mathrm{~g}, 47.8 \mathrm{mmol})$ was dissolved in $\mathrm{MeOH}$ and treated with solid $\mathrm{Boc}_{2} \mathrm{O}(52.0 \mathrm{~g}$, $239 \mathrm{mmol}$ ). The mixture was stirred at reflux for $18 \mathrm{~h}$. Upon completion of the reaction (as judged by TLC), the volatiles were removed and the crude material was placed under reduced pressure (hi-vac) to ensure evaporation of the bulk of remaining $\mathrm{Boc}_{2} \mathrm{O}$ (monitored by ${ }^{1} \mathrm{H} N M R$ ). The crude material was then dissolved in THF and cooled to $0{ }^{\circ} \mathrm{C}$. A solution of $\mathrm{LiBH}_{4}(4 \mathrm{M}$ in THF, $95.6 \mathrm{~mL}, 382 \mathrm{mmol}$ ) was added dropwise, the solution warmed to rt over $12 \mathrm{~h}$, then quenched with dropwise addition of sat. aq. $\mathrm{NH}_{4} \mathrm{Cl}$. The product was extracted with EtOAc, dried with $\mathrm{MgSO}_{4}$, and volatiles were removed under reduced pressure. Purification via flash chromatography over silica gel (0-10\% EtOAc/hexanes) afforded a 8 as a yellow oil ( $13.7 \mathrm{~g}, 59 \%$ yield). ${ }^{1} \mathrm{H}$ NMR (400 MHz, $\mathrm{CDCl}_{3}$, mixture of rotamers): $\delta 5.94(\mathrm{~m}, 1 \mathrm{H}), 4.49-3.74(\mathrm{~m}, 6.5 \mathrm{H}), 3.42(\mathrm{~m}, 0.5 \mathrm{H}), 1.78(\mathrm{~d}, J 6.4 \mathrm{~Hz}$, 3H), $1.42(\mathrm{~s}, 9 \mathrm{H}) 0.85(\mathrm{~m}, 9 \mathrm{H}), 0.03(\mathrm{~s}, 6 \mathrm{H}) ;{ }^{13} \mathrm{C} \mathrm{NMR}\left(100 \mathrm{MHz}, \mathrm{CDCl}_{3}\right): \delta 131.9,107.2,81.0,63.8,62.2,62.0$, 60.8, 28.6, 26.1. 21.8, 18.3, -5.3; HRMS (ESI-TOF) $m / z[\mathrm{M}+\mathrm{H}]^{+}$calcd for $\mathrm{C}_{19} \mathrm{H}_{36} \mathrm{INO} \mathrm{NO}_{5} \mathrm{Si} 486.1531$, found 486.1501 .

Methyl (R,E)-4-((tert-butoxycarbonyl)((Z)-2-iodobut-2-en-1-yl)amino)-5-((tert-butyldimethylsilyl)oxy) pent-2enoate (9). A solution of oxalyl chloride $(2.65 \mathrm{~mL}, 30.8 \mathrm{mmol})$ in $\mathrm{DCM}$ was cooled to $-78^{\circ} \mathrm{C}$ and treated with DMSO $(4.37 \mathrm{~mL}, 61.6 \mathrm{mmol}$ ) dropwise over $5 \mathrm{~min}$. After stirring for 30 minutes, a solution of compound 8 (4.98 g, $10.3 \mathrm{mmol}$ ) in DCM was added dropwise and the reaction was stirred for $45 \mathrm{~min}$ at $-78{ }^{\circ} \mathrm{C}$. Triethylamine $(14.3 \mathrm{~mL}, 103 \mathrm{mmol})$ was added and the solution was warmed to $\mathrm{rt}$. The reaction was quenched with sat. aq. $\mathrm{NH}_{4} \mathrm{Cl}$ and extracted with EtOAc. The combined organic layers were dried with $\mathrm{Na}_{2} \mathrm{SO}_{4}$ and concentrated under reduced pressure. The crude material was triturated with a small amount of diethyl ether and the suspension filtered through a celite plug. Concentration of the filtrate gave the crude aldehyde, which was dissolved in DCM and treated directly with methyl(triphenylphosphoranylidene)acetate (7.83 g, 23.4 $\mathrm{mmol}$ ). After stirring at $\mathrm{rt}$ for $16 \mathrm{~h}$, the reaction was quenched with sat. aq. $\mathrm{NH}_{4} \mathrm{Cl}$, extracted with EtOAc, and dried over $\mathrm{Na}_{2} \mathrm{SO}_{4}$. Concetration under reduced pressure and purification via flash chromatography over silica gel (0-25\% EtOAc/hexanes) afforded a 9 as a yellow oil $\left(3.82 \mathrm{~g}, 70 \%\right.$ yield over two steps). ${ }^{1} \mathrm{H} \mathrm{NMR}(400 \mathrm{MHz}$, $\left.\mathrm{CDCl}_{3}\right) \delta 7.04(\mathrm{dd}, J 10.6 \mathrm{~Hz}, 1 \mathrm{H}), 5.88(\mathrm{~d}, J 17.1 \mathrm{~Hz}, 1 \mathrm{H}), 5.81(\mathrm{~m}, 1 \mathrm{H}), 4.40-3.80(\mathrm{~m}, 5 \mathrm{H}), 3.73(\mathrm{~s}, 3 \mathrm{H}), 1.77(\mathrm{~d}, J$ $6.3 \mathrm{~Hz}, 3 \mathrm{H}), 1.44(\mathrm{~s}, 9 \mathrm{H}), 0.87(\mathrm{~s}, 9 \mathrm{H}) ;{ }^{13} \mathrm{C} \mathrm{NMR}\left(100 \mathrm{MHz}, \mathrm{CDCl}_{3}\right.$, mixture of rotamers): $\delta 166.2,154.5,154.4$, 145.7, 144.7, 131.8 130.5, 122.1, 121.5, 106.7, 106.2 80.6, 80.2, 63.8, 63.2, 59.6, 58.9, 58.7, 51.3, 31.5, 28.2, 25.7, 22.5, 21.5, 18.0, 14.0, -5.52; HRMS (ESI-TOF) $\mathrm{m} / \mathrm{z}[\mathrm{M}+\mathrm{H}]^{+}$calcd for $\mathrm{C}_{21} \mathrm{H}_{39} \mathrm{INO}_{5} \mathrm{Si}$ 540.1637, found 539.1599.

\section{tert-Butyl-(2R,3R,E)-2-(((tert-butyldimethylsilyl)oxy)methyl)-4-ethylidene-3-(2-methoxy-2-}

oxoethyl)pyrrolidine-1-carboxylate (10). Compound 9 (3.65 g, $6.77 \mathrm{mmol}$ ) was dissolved in MeCN containing a small amount of water $(240 \mu \mathrm{L}, 13.5 \mathrm{mmol})$. This solution was placed in a sealed vial and Ar was bubbled through the solution for $30 \mathrm{~min}$. A separate sealed vial containing activated zinc (1.11 $\mathrm{g}, 16.9 \mathrm{mmol})$ and $\mathrm{Ni}\left(\mathrm{PPh}_{3}\right)_{2} \mathrm{Cl}_{2}(0.886 \mathrm{~g}, 1.35 \mathrm{mmol})$ under $\mathrm{Ar}$ was treated with the above solution of 9 via cannula. The suspension was heated to $80{ }^{\circ} \mathrm{C}$ for $1 \mathrm{~h}$. The reaction was allowed to cool to $\mathrm{rt}$, then filtered through a celite plug. The filtrate was concentrated and purified via flash chromatography over silica gel (10\% EtOAc/hexanes) to afford a 10 as a light yellow oil ( $1.90 \mathrm{~g}, 68 \%$ yield) ${ }^{1} \mathrm{H} \mathrm{NMR}$ (400 MHz, CDCl 3 , mixture of rotamers): $\delta 5.41$ $(\mathrm{m}, 1 \mathrm{H}), 4.50(\mathrm{~m}, 1 \mathrm{H}), 3.79(\mathrm{~m}, 1 \mathrm{H}), 3.66(\mathrm{~m}, 4.5 \mathrm{H}), 3.39(\mathrm{~m}, 0.5 \mathrm{H}), 3.27(\mathrm{~m}, 1 \mathrm{H}), 2.38(\mathrm{~m}, 2 \mathrm{H}), 1.36(\mathrm{~m}, 3 \mathrm{H})$, $1.44(\mathrm{~s}, 9 \mathrm{H}), 0.85-0.84(\mathrm{~m}, 9 \mathrm{H}), 0.00(\mathrm{~s}, 6 \mathrm{H}) ;{ }^{13} \mathrm{C} \mathrm{NMR}\left(100 \mathrm{MHz}, \mathrm{CDCl}_{3}\right.$, mixture of rotamers): $\delta 172.5,154.5$, 
139.3, 138.0, 118.3, 117.3, 79.8, 79.5, 64.4, 64.3, 63.8, 63.5, 51.9, 51.8, 51.0, 50.3, 39.5, 38.9, 38.2, 28.7, 25.9, 18.3, 14.2, -5.3. HRMS (ESI-TOF) $\mathrm{m} / 2[\mathrm{M}+\mathrm{H}]^{+}$calcd for $\mathrm{C}_{21} \mathrm{H}_{40} \mathrm{NO}_{5} \mathrm{Si} 414.2670$, found 414.2687.

tert-Butyl (2R,3R,E)-2-(((tert-butyldimethylsilyl)oxy)methyl)-4-ethylidene-3-(2-(methoxy(methyl) amino)-2oxoethyl)pyrrolidine-1-carboxylate (11). Compound $10(1.05 \mathrm{~g}, 2.54 \mathrm{mmol})$ and $\mathrm{MeNH}(\mathrm{OMe}) \cdot \mathrm{HCl}(743 \mathrm{mg}$, $7.62 \mathrm{mmol}$ ) were placed under $\mathrm{Ar}$, dissolved in THF and cooled to $-10{ }^{\circ} \mathrm{C}$. A solution of $\operatorname{PrMgCl}(2.0 \mathrm{M}$ in $\mathrm{THF}$, $7.00 \mathrm{~mL}, 14.0 \mathrm{mmol}$ ) was added dropwise. After stirring $1 \mathrm{~h}$, the reaction mixture was warmed to rt, washed with sat. aq. $\mathrm{NH}_{4} \mathrm{Cl}$, and the aqueous layer extracted with EtOAc. The combined organic layers were dried over $\mathrm{Na}_{2} \mathrm{SO}_{4}$ and concentrated. The crude material was purified via flash chromatography over silica gel (10-50\% EtOAc/hexanes) to afford 11 as a brownish oil (1.07 g, 95\% yield). ${ }^{1} \mathrm{H} \mathrm{NMR} \mathrm{(400} \mathrm{MHz}, \mathrm{CDCl}_{3}$, mixture of rotamers): $\delta 5.04(\mathrm{~m}, 1 \mathrm{H}), 3.77(\mathrm{~m}, 1 \mathrm{H}), 3.51-3.28(\mathrm{~m}, 6.5 \mathrm{H}), 3.21(\mathrm{~m}, 0.5 \mathrm{H}), 3.01(\mathrm{~m}, 1 \mathrm{H}), 2.84(\mathrm{~m}, 3 \mathrm{H}), 2.16$ $(\mathrm{m}, 2 \mathrm{H}), 1.32(\mathrm{~m}, 3 \mathrm{H}), 1.13(\mathrm{~s}, 9 \mathrm{H}), 0.53(\mathrm{~s}, 9 \mathrm{H}),-0.32(\mathrm{~s}, 6 \mathrm{H}) ;{ }^{13} \mathrm{C} \mathrm{NMR}\left(100 \mathrm{MHz}, \mathrm{CDCl}_{3}\right.$, mixture of rotamers): $\delta$ 171.9, 153.7, 139.6, 138.5, 116.4, 115.7, 78.6, 78.4, 63.9, 63.8, 63.6, 63.1, 60.6, 50.6, 50.0, 38.8, 38.0, 35.3, 31.5, 28.0, 25.3, 17.6, 13.4, 6.1; HRMS (ESI-TOF) $\mathrm{m} / \mathrm{z}[\mathrm{M}+\mathrm{H}]^{+}$calcd for $\mathrm{C}_{22} \mathrm{H}_{43} \mathrm{~N}_{2} \mathrm{O}_{5} \mathrm{Si} 442.2863$, found 442.2875. tert-Butyl 3-(2,2-dimethoxyethyl)-1H-indole-1-carboxylate (13) Aldehyde $12^{28}$ (2.60 g, $9.06 \mathrm{mmol}$ ) was dissolved in trimethylorthoformate $(10.6 \mathrm{~mL}, 96.6 \mathrm{mmol})$ and freshly recrystallized pyridinium $p$ toluenesulfonate (114 mg, $453 \mu \mathrm{mol}$ ) was added in one portion. The reaction mixture was placed under Ar and stirred at $\mathrm{rt}$ for $16 \mathrm{~h}$. The reaction mixture was then filtered and evaporated, and the crude material purified via flash chromatography over silica gel (0-40\% EtOAc/hexanes) to afford 13 as a yellow oil ( $2.32 \mathrm{~g}, 84 \%$ yield). ${ }^{1} \mathrm{H}$ NMR $\left(400 \mathrm{MHz}, \mathrm{CDCl}_{3}\right): \delta 8.13(\mathrm{~m}, 1 \mathrm{H}), 7.56(\mathrm{~m}, 1 \mathrm{H}), 7.48(\mathrm{~s}, 1 \mathrm{H}), 7.31(\mathrm{t}, J 7.3 \mathrm{~Hz}, 1 \mathrm{H}), 7.24(\mathrm{~m}, 1 \mathrm{H}), 4.68(\mathrm{t}$, J $5.6 \mathrm{~Hz}, 1 \mathrm{H}), 3.38(\mathrm{~s}, 6 \mathrm{H}), 3.00(\mathrm{~d}, J=5.55 \mathrm{~Hz}, 2 \mathrm{H}), 1.67(\mathrm{~s}, 9 \mathrm{H}) ;{ }^{13} \mathrm{C} \mathrm{NMR}\left(100 \mathrm{MHz}, \mathrm{CDCl}_{3}\right.$, mixture of rotamers): $\delta 149.9,135.5,131.0,124.4,124.0,122.5,119.2,115.9,115.4,104.2,104.1,83.6,53.5,53.4,29.2,28.4$; HRMS (ESI-TOF) $\mathrm{m} / z$ [M+Na] $]^{+}$calcd for $\mathrm{C}_{17} \mathrm{H}_{23} \mathrm{INO}_{4} \mathrm{Na} 328.1519$, found 328.1511.

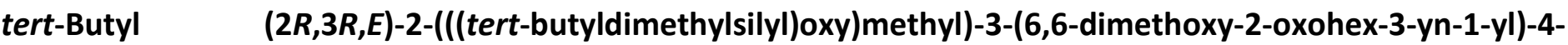
ethylidenepyrrolidine-1-carboxylate (16). 4,4-Dimethoxybut-1-yne ${ }^{19}$ (206 mg, $1.45 \mathrm{mmol}$ ) was dissolved in dry $\mathrm{THF}$, placed in a sealed vial, and cooled to $0{ }^{\circ} \mathrm{C}$. A solution of EtMgBr (0.9 M in THF, $\left.1.50 \mathrm{~mL}, 1.36 \mathrm{mmol}\right) \mathrm{was}$ added and the reaction was heated to $60{ }^{\circ} \mathrm{C}$ for $3 \mathrm{~h}$ and cooled to rt. A separate sealed flask containing compound 11 (207 mg, $468 \mu \mathrm{mol}$ ) dissolved in THF under Ar was treated with the organometallic solution via cannula. After strirring $1 \mathrm{~h}$ at $\mathrm{rt}$, the reaction mixture was quenched then washed with sat. aq. $\mathrm{NH}_{4} \mathrm{Cl}$, and the aqueous layer extracted with EtOAc. The combined organic layers were dried over $\mathrm{Na}_{2} \mathrm{SO}_{4}$ and concentrated. The crude material was purified by flash chromatography over silica gel (0-40\% EtOAc/hexanes), affording 16 as a light yellow oil $\left(208 \mathrm{mg}, 86 \%\right.$ yield). ${ }^{1} \mathrm{H}$ NMR $\left(400 \mathrm{MHz}^{\mathrm{C} C D C l}{ }_{3}\right.$, mixture of rotamers): $\delta 5.27(\mathrm{~m}, 1 \mathrm{H}), 4.46$ $(\mathrm{m}, 1 \mathrm{H}), 3.98-3.87(\mathrm{~m}, 1 \mathrm{H}), 3.65(\mathrm{~m}, 1 \mathrm{H}), 3.53(\mathrm{~m}, 2 \mathrm{H}), 3.34(\mathrm{~m}, 0.5 \mathrm{H}), 3.25(\mathrm{~s}, 8 \mathrm{H}), 2.65-2.41(\mathrm{~m}, 4 \mathrm{H}), 1.53(\mathrm{~m}$, $3 \mathrm{H}), 1.33(\mathrm{~s}, 9 \mathrm{H}), 0.74(\mathrm{~s}, 9 \mathrm{H}),-0.11(\mathrm{~s}, 6 \mathrm{H}) ;{ }^{13} \mathrm{C} \mathrm{NMR}\left(100 \mathrm{MHz}, \mathrm{CDCl}_{3}\right.$, mixture of rotamers): $\delta 185.6,154.2$, 139.2, 138.0, 117.4, 116.8, 101.5, 89.0, 82.0, 79.4, 79.2, 64.0, 63.7, 63.3, 53.5, 50.8, 49.1, 48.9, 38.5, 37.8, 28.4, 25.7, 24.3, 18.1, 14.0, -5.6; HRMS (ESI-TOF) $\mathrm{m} / \mathrm{z}[\mathrm{M}+\mathrm{H}]^{+}$calcd for $\mathrm{C}_{26} \mathrm{H}_{46} \mathrm{NO}_{6} \mathrm{Si} 496.3089$, found 496.3128.

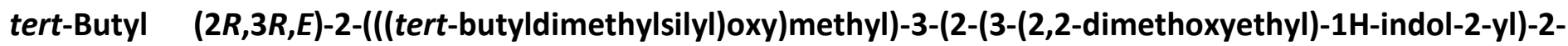
oxoethyl)-4-ethylidenepyrrolidine-1-carboxylate (15). A solution of 16 (1.15 g, $2.20 \mathrm{mmol})$ in dry THF was thoroughly purged with Ar. A separate sealed vial charged with 2-iodoaniline (578 mg, $2.64 \mathrm{mmol}), \mathrm{Pd}_{(}\left(\mathrm{PPh}_{3}\right)_{4}$ $(507 \mathrm{mg}, 440 \mu \mathrm{mol})$, and $\mathrm{K}_{2} \mathrm{CO}_{3}(607 \mathrm{mg}, 4.40 \mathrm{mmol})$ was treated with the above solution via cannula. The suspension was vigorously stirred at $70{ }^{\circ} \mathrm{C}$ for $16 \mathrm{~h}$. The reaction mixture was washed with sat. aq. $\mathrm{NH}_{4} \mathrm{Cl}$, and the aqueous layer extracted with EtOAc. The combined organic layers were dried over $\mathrm{Na}_{2} \mathrm{SO}_{4}$ and concentrated. The crude material was purified by flash chromatography over silica gel (0-50\% EtOAc/hexanes), 
affording 15 as a yellow solid (702 mg, 55\% yield). ${ }^{1} \mathrm{H} \mathrm{NMR} \mathrm{(400} \mathrm{MHz,} \mathrm{CDCl}_{3}$, mixture of rotamers): $\delta 9.29$ (s, $0.5 \mathrm{H}), 9.14(\mathrm{~s}, 0.5 \mathrm{H}), 7.68(\mathrm{~m}, 1 \mathrm{H}), 7.33(\mathrm{~m}, 2 \mathrm{H}), 7.10(\mathrm{~m}, 1 \mathrm{H}), 5.29(\mathrm{~m}, 1 \mathrm{H}), 4.55(\mathrm{~m}, 1 \mathrm{H}), 4.12(\mathrm{~m}, 1 \mathrm{H}), 3.89-$ $3.59(\mathrm{~m}, 4 \mathrm{H}), 3.50(\mathrm{~m}, 1 \mathrm{H}), 3.33(\mathrm{~m}, 9 \mathrm{H}), 3.08(\mathrm{~m}, 1 \mathrm{H}), 1.59(\mathrm{~m}, 3 \mathrm{H}), 1.49-1.31(\mathrm{~m}, 9 \mathrm{H}), 0.84,(\mathrm{~d}, J=5.3 \mathrm{~Hz}, 9 \mathrm{H})$, $0.00,(\mathrm{~m}, 6 \mathrm{H}) ;{ }^{13} \mathrm{C} \mathrm{NMR}\left(100 \mathrm{MHz}, \mathrm{CDCl}_{3}\right.$, mixture of rotamers): $\delta 192.3,154.6,140.3,139.1,136.1,133.0$, 128.8, 126.4, 121.5. 120.5, 117.8, 117.5, 117.0, 116.4, 112.2, 106.1, 105.6, 79.8, 79.4, 65.0, 64.4, 63.9, 54.5, 51.4, 44.2, 38.8, 37.9, 30.6, 28.7, 25.9, 18.4, 14.2, -5.3; HRMS (ESI-TOF) $\mathrm{m} / z[\mathrm{M}+\mathrm{H}]^{+}$calcd for $\mathrm{C}_{32} \mathrm{H}_{51} \mathrm{~N}_{2} \mathrm{O}_{6} \mathrm{Si}$ 587.3511 , found 587.3492 .

\section{1-(tert-Butyl) 2-methyl (2S,3S,E)-3-(2-(3-(2,2-dimethoxyethyl)-1H-indol-2-yl)-2-oxoethyl)-4-} ethylidenepyrrolidine-1,2-dicarboxylate (17). A solution of compound 15 (245 mg, $418 \mu \mathrm{mol}$ ) was dissolved in THF and treated with TBAF (1M in THF, $1.67 \mathrm{~mL}, 1.67 \mathrm{mmol})$ dropwise. The reaction was stirred for $1 \mathrm{~h}$, washed with sat. aq. $\mathrm{NH}_{4} \mathrm{Cl}$, and the aqueous layer extracted with EtOAc. The combined organic layers were dried over $\mathrm{Na}_{2} \mathrm{SO}_{4}$ and concentrated. The crude material was purified via flash chromatography over silica gel (30-70\% EtOAc/hexanes) to give the intermediate alcohol as a yellow solid (184 $\mathrm{mg}, 94 \%$ yield). This unstable solid was immediately dissolved in $1: 1 \mathrm{H}_{2} \mathrm{O} / \mathrm{MeCN}$, cooled to $0{ }^{\circ} \mathrm{C}$, and treated with solid $\mathrm{NaHCO}_{3}(62.3 \mathrm{mg}$, $741 \mu \mathrm{mol})$, (bisacetoxyiodo)benzene $(263 \mathrm{mg}, 815 \mu \mathrm{mol})$ and TEMPO (12 mg, $74 \mu \mathrm{mol})$. The reaction was stirred for $2 \mathrm{~h}$, then $1 \mathrm{M}$ aq. $\mathrm{HCl}$ was added dropwise until a $\mathrm{pH}$ of 3 was attained. The aqueous layer was extracted with EtOAc, and the combined organic layers dried over $\mathrm{Na}_{2} \mathrm{SO}_{4}$ and concentrated. The resulting yellow oil was dissolved in $20 \% \mathrm{MeOH} /$ toluene and treated with trimethylsilyldiazomethane $\left(2 \mathrm{M}\right.$ in $\mathrm{Et}_{2} \mathrm{O}, 927$ $\mu \mathrm{L}, 1.85 \mathrm{mmol}$ ) was added. The solution was stirred for $1 \mathrm{~h}$, concentrated under vacuum, and the material purified via flash chromatography over silica gel (10-55\% EtOAc/hexanes) to provide 17 as a yellow oil (123 $\mathrm{mg}, 64 \%$ yield over three steps). ${ }^{1} \mathrm{H} \mathrm{NMR}\left(400 \mathrm{MHz}^{\mathrm{CDCl}} 3\right.$, mixture of rotamers): $\delta 9.15(\mathrm{~s}, 1 \mathrm{H}), 7.31(\mathrm{~m}, 1 \mathrm{H})$, $7.37(\mathrm{~m}, 2 \mathrm{H}), 7.15(\mathrm{~m}, 1 \mathrm{H}), 5.45(\mathrm{~m}, 1 \mathrm{H}), 4.55(\mathrm{~m}, 1 \mathrm{H}) 4.39(\mathrm{~m}, 0.5 \mathrm{H}), 4.25(\mathrm{~m}, 0.5 \mathrm{H}), 4.15(\mathrm{~m}, 2 \mathrm{H}), 3.78(\mathrm{~m}, 3 \mathrm{H})$, $3.67(\mathrm{~m}, 1 \mathrm{H}), 3.55-3.42(\mathrm{~m}, 1.5 \mathrm{H}), 3.44-3.30(\mathrm{~m}, 8 \mathrm{H}), 3.20(\mathrm{~m}, 0.5 \mathrm{H}), 1.63(\mathrm{~m}, 3 \mathrm{H}), 1.51-1.34(\mathrm{~m}, 9 \mathrm{H}) ;{ }^{13} \mathrm{C} \mathrm{NMR}$ (100 MHz, $\mathrm{CDCl}_{3}$, mixture of rotamers): $\delta$ 191.6, 172.8, 155.1, 154.6, 137.9, 136.9, 136.1, 132.9, 128.8, 126.7, $126.5,121.5,121.3,120.7,118.7,117.7,117.5,112.2,106.0,105.7,80.4,65.1,64.5,54.8,54.6,52.5,50.3$, 43.9, 40.4, 39.7, 30.6, 28.6, 28.5, 14.3; HRMS (ESI-TOF) $m / z[M+N a]^{+}$calcd for $\mathrm{C}_{27} \mathrm{H}_{36} \mathrm{IN}_{2} \mathrm{O}_{7} \mathrm{Na} 523.2415$, found 523.2421.

1-(tert-Butyl) 2-methyl (2S,3S,E)-3-(2-(3-(2,2-dimethoxyethyl)-1H-indol-2-yl)-2-oxoethyl)-4ethylidenepyrrolidine-1,2-dicarboxylate (18). A solution of compound 17 (37.4 mg, $75 \mu \mathrm{mol}$ ) in $\mathrm{MeOH}$ was cooled to $0{ }^{\circ} \mathrm{C}$ and treated dropwise with acetyl chloride $(267 \mu \mathrm{L}, 3.75 \mathrm{mmol})$. Upon consumption of starting material by TLC, $(1.5 \mathrm{~h})$ the solution was neutralized with triethylamine, the volitiles removed under vacuum, and the crude material suspended in $\mathrm{Et}_{2} \mathrm{O}$. This suspension was filtered and the filtrate concentrated under vacuum. The crude intermediate was dissolved in $\mathrm{DCM}$ and cooled to $0{ }^{\circ} \mathrm{C}$. Trifluorethanol $(1.12 \mathrm{~mL}, 14.5$ $\mathrm{mmol}$ ) and one drop of $12 \mathrm{M}$ aq. $\mathrm{HCl}$ were added and the reaction stirred at $0{ }^{\circ} \mathrm{C}$ until all starting material was consumed as judged by TLC. The reaction was quenched with sat aq. $\mathrm{NaHCO}_{3}$ and extracted with DCM. The combined organic layers were dried over $\mathrm{Na}_{2} \mathrm{SO}_{4}$, concentrated, and the crude material purified via flash chromatography over silica gel (0-10\% MeOH/DCM) to give 18 as a yellow solid (20 mg, 40\% yield). ${ }^{1} \mathrm{H} N M R$ $\left(400 \mathrm{MHz}_{2} \mathrm{CDCl}_{3}\right) \delta 8.88(\mathrm{~s}, 2 \mathrm{H}), 7.69,(\mathrm{~d}, J 8.2 \mathrm{~Hz}, 2 \mathrm{H}), 7.28(\mathrm{~m}, 4 \mathrm{H}) ; 7.03(\mathrm{~m}, 2 \mathrm{H}), 6.67(\mathrm{~d}, J 13.8 \mathrm{~Hz}, 2 \mathrm{H}), 5.63$ $(\mathrm{m}, 2 \mathrm{H}), 5.34(\mathrm{~d}, J 13.8 \mathrm{~Hz}, 2 \mathrm{H}), 4.08-3.98(\mathrm{~m}, 2 \mathrm{H}), 3.97-3.82(\mathrm{~m}, 6 \mathrm{H}), 3.81-3.74(\mathrm{~m}, 8 \mathrm{~h}), 2.56(\mathrm{~m}, 2 \mathrm{H}), 1.84(\mathrm{~d}, J$ $6.6 \mathrm{~Hz}, 6 \mathrm{H}) ;{ }^{13} \mathrm{C} \mathrm{NMR}\left(100 \mathrm{MHz}, \mathrm{CDCl}_{3}\right): \delta 190.1,172.5,139.9,137.8,137.3,131.5,127.8,127.4,124.8,123.1$, 120.5, 119.0, 111.9, 89.8, 68.6, 52.6, 50.6, 41.7, 41.4, 29.9, 14.4; HRMS (ESI-TOF) $\mathrm{m} / z$ [M+Na] ${ }^{+}$calcd for $\mathrm{C}_{40} \mathrm{H}_{40} \mathrm{IN}_{4} \mathrm{O}_{6} \mathrm{Na} 695.2840$, found 695.2864 . A portion of the solid was recrystallized from $\mathrm{CHCl}_{3} / \mathrm{hexanes}$ by 
vapor diffusion to give a sample suitable for X-ray diffraction. The CIF file was deposited in the Cambridge Crystallographic Data Centre (CCDC 1892734).

\section{Acknowledgements}

Copies of ${ }^{1} \mathrm{H}$ and ${ }^{13} \mathrm{C}$ NMR are available in the supplementary material. X-Ray crystallographic data for compound 18 are included.

\section{Supplementary Material}

We thank Dr. Lukasz Wojtas for X-ray structure determination of $\mathbf{1 8}$, and the USF Interdisciplinary NMR and Mass Spectrometry facilities for assistance with compound characterizations. This work was supported by the University of South Florida.

\section{References}

1. Qureshi, A. A.; Scott, A. I. Chem. Comm. 1968, 945.

2. O'Connor, S. E.; Maresh, J. J. Nat Prod. Rep. 2006, 23, 532. https://doi.org/10.1039/b512615k

3. Mansoor, T. A.; Ramalho, R. M.; Mulhovo, S.; Rodrigues, C. M.; Ferreira, M. J. Bioorg. Med. Chem. Lett. 2009, 19, 4255. https://doi.org/10.1016/j.bmcl.2009.05.104

4. Layne, T. H.; McLean, S.; Reynolds, W. F.; Tinto, W. F. Nat. Prod. Comm. 2007, 2, 649.

5. Ahmad, K.; Hirasawa, Y.; Nugroho, A. E. Heterocycles 2012, 86, 1611. https://doi.org/10.3987/COM-12-S(N)113

6. Zhang, L.; Zhang, C.-J.; Zhang, D.-B.; Wen, J.; Zhao, X.-W.; Li, Y.; Gao, K. Tetrahedron Lett. 2014, $55,1815$. https://doi.org/10.1016/i.tetlet.2014.01.122

7. Jarret, M.; Tap, A.; Kouklovsky, C.; Poupon, E.; Evanno, L.; Vincent, G. Angew. Chem. Int. Ed. 2018, 57, 12294. https://doi.org/10.1002/anie.201802610

8. Pal, U.; Ranatunga, S.; Ariyarathna, Y.; Del Valle, J. R. Org. Lett. 2009, 11, 5298. https://doi.org/10.1021/ol902251c

9. Ranatunga, S.; Kim, J. S.; Pal, U.; Del Valle, J. R. J. Org. Chem. 2011, 76, 8962. https://doi.org/10.1021/jo201727g

10. Ranatunga, S.; Tang, C. H.; Hu, C. C.; Del Valle, J. R. J. Org. Chem. 2012, 77, 9859. https://doi.org/10.1021/jo301723y

11. Cho, J. Y.; Williams, P. G.; Kwon, H. C.; Jensen, P. R.; Fenical, W. J. Nat. Prod. 2007, 70, 1321. https://doi.org/10.1021/np070101b

12. Cha, J. W.; Park, J. S.; Sim, T.; Nam, S. J.; Kwon, H. C.; Del Valle, J. R.; Fenical, W. J. Nat. Prod. 2012, 75, 1648. 
13. Zaman, L.; Arakawa, O.; Shimosu, A.; Onoue, Y. Toxicon 1997, 35, 423.

https://doi.org/10.1016/S0041-0101(96)00167-5

14. Hurley, L. H.; Gairola, C.; Das, N. V. Biochemistry 1976, 15, 3760.

https://doi.org/10.1021/bi00662a019

15. Tozuka, Z.; Takaya, T. J. Antibiot. 1983, 36, 142.

https://doi.org/10.7164/antibiotics.36.142

16. Bartoli, G.; Di Antonio, G.; Fiocchi, R.; Giuli, S.; Marcantoni, E.; Marcolini, M. Synthesis 2009, $2009,951$.

17. Martin, D. B. C.; Nguyen, L. Q.; Vanderwal, C. D. J. Org. Chem. 2012, 77, 17. https://doi.org/10.1021/jo2020246

18. Pelkey, E. T. In Heterocyclic Scaffolds II: Reactions and Applications of Indoles; Gribble, G. W., Ed.; Springer Berlin Heidelberg: Berlin, Heidelberg, 2010, p 141.

https://doi.org/10.1007/7081 201056

19. Shang, S.; Iwadare, H.; Macks, D. E.; Ambrosini, L. M.; Tan, D. S. Org. Lett. 2007, 9, 1895. https://doi.org/10.1021/ol070405p

20. Larock, R. C.; Yum, E. K.; Refvik, M. D. J. Org. Chem. 1998, 63, 7652.

https://doi.org/10.1021/jo9803277

21. Liang, J.; Hu, W.; Tao, P.; Jia, Y. J. Org. Chem. 2013, 78, 5810.

https://doi.org/10.1021/jo400841d

22. Gavara, L.; Anizon, F.; Moreau, P. Tetrahedron 2011, 67, 7330.

https://doi.org/10.1016/i.tet.2011.07.029

23. Zhang, H.-C.; Brumfield, K. K.; Maryanoff, B. E. Tetrahedron Lett. 1997, 38, 2439. https://doi.org/10.1016/S0040-4039(97)00417-6

24. Phetrak, N.; Rukkijakan, T.; Sirijaraensre, J.; Prabpai, S.; Kongsaeree, P.; Klinchan, C.; Chuawong, P. J. Org. Chem. 2013, 78, 12703.

https://doi.org/10.1021/j0402304s

25. Ahond, A.; Bui, A. M.; Potier, P.; Hagaman, E. W.; Wenkert, E. J. Org. Chem. 1976, 41, 1878. https://doi.org/10.1021/jo00872a046

26. Cava, M. P.; Talapatra, S. K.; Weisbach, J. A.; Douglas, B.; Dudek, G. O. Tetrahedron Lett. 1963, 4, 53. https://doi.org/10.1016/S0040-4039(01)90576-3

27. Girardot, M.; Deregnaucourt, C.; Deville, A.; Dubost, L.; Joyeau, R.; Allorge, L.; Rasoanaivo, P.; Mambu, L. Phytochemistry 2012, 73, 65. https://doi.org/10.1016/i.phytochem.2011.09.012

28. Ghosh, N.; Nayak, S.; Sahoo, A. K. J. Org. Chem. 2011, 76, 500. https://doi.org/10.1021/jo101995g 